\title{
Micro-CT - a digital 3D microstructural voyage into scaffolds: a systematic review of the reported methods and results
}

\author{
Ibrahim Fatih Cengiz ${ }^{1,2^{*}}$, Joaquim Miguel Oliveira ${ }^{1,2,3}$ and Rui L. Reis ${ }^{1,2,3}$
}

\begin{abstract}
Background: Cell behavior is the key to tissue regeneration. Given the fact that most of the cells used in tissue engineering are anchorage-dependent, their behavior including adhesion, growth, migration, matrix synthesis, and differentiation is related to the design of the scaffolds. Thus, characterization of the scaffolds is highly required. Micro-computed tomography (micro-CT) provides a powerful platform to analyze, visualize, and explore any portion of interest in the scaffold in a 3D fashion without cutting or destroying it with the benefit of almost no sample preparation need.

Main body: This review highlights the relationship between the scaffold microstructure and cell behavior, and provides the basics of the micro-CT method. In this work, we also analyzed the original papers that were published in 2016 through a systematic search to address the need for specific improvements in the methods section of the papers including the amount of provided information from the obtained results.

Conclusion: Micro-CT offers a unique microstructural analysis of biomaterials, notwithstanding the associated challenges and limitations. Future studies that will include micro-CT characterization of scaffolds should report the important details of the method, and the derived quantitative and qualitative information can be maximized.
\end{abstract}

Keywords: Systematic review, Microstructure, Mineral density, Scaffolds, Tissue engineering

\section{Background}

In nature, structural materials including animal and human tissues have complex hierarchical architectures at multiple scales from nano to macro [1]. To achieve the regeneration of functional tissues, as in nature, complete understanding and biomimicry of those 3D architectures are necessary. Differences in the design of 3D scaffolds [2] such as composition, surface chemistry, architecture, and mechanical properties, can yield to almost countless different scaffolds. Scaffolds host and interact with cells, and the design of a scaffold affects the entire behavior of the cells including adhesion, growth, migration, differentiation, and matrix synthesis [3-8]. Certainly, the functional

\footnotetext{
* Correspondence: fatih.cengiz@i3bs.uminho.pt

'3B's Research Group, I3Bs - Research Institute on Biomaterials,

Biodegradables and Biomimetics, University of Minho, Headquarters of the European Institute of Excellence on Tissue Engineering and Regenerative Medicine, AvePark, Parque de Ciência e Tecnologia, Zona Industrial da Gandra, Barco, 4805-017 Guimarães, Portugal

${ }^{2}$ ICVS/3B's - PT Government Associate Laboratory, Braga/Guimarães, Portugal Full list of author information is available at the end of the article
}

performance of a scaffold in vivo not only depends on its microstructure but also on all other factors involved in tissue engineering which are very complex and probably not yet completely known [9].

Tomography is defined as a method by which an object's 3D image that corresponds to its internal structure is obtained. Micro-computed tomography (micro-CT) $[10,11]$ is a high-resolution CT that has a pixel size typically between $1 \mu \mathrm{m}$ and $50 \mu \mathrm{m}$, and allows to investigate the microstructure of samples using X-rays. Conventionally, the samples can be analyzed almost without any sample preparation process generally in a non-destructive way. Today, a search on "micro-CT" in PubMed yields more than 10,000 items by being used in many fields. Within the field of tissue engineering it has a place in many application domains including (i) scaffold characterization [12-15], (ii) in vivo small laboratory animal tissue characterization [16-19] including assessment of bone turnover using 4D micro-CT data [20], and tumor detection [19], (iii) ex vivo characterization of human tissues

(c) The Author(s). 2018 Open Access This article is distributed under the terms of the Creative Commons Attribution 4.0 International License (http://creativecommons.org/licenses/by/4.0/), which permits unrestricted use, distribution, and 
[21, 22] and animal tissues [23-27]. Micro-CT has frequently been used in bone studies, and typically, the investigated parameters include volume, microstructural features, and mineral density. The investigation of soft tissues is relatively challenging due to their low contrast in conventional micro-CT imaging; thus it may require an extra effort such as employing high-atomic-number element probes [28] or contrast agents [29-32].

\section{D Microstructural metrology of scaffolds used in tissue engineering with tomography}

Given the critical role of microstructure on the performance of scaffolds, characterization of the microstructure is indispensable, and Micro-CT is an outstanding instrument to characterize the microstructure of scaffolds. A large surface area assists cell attachment and proliferation. Porosity and pore size define the surface area per volume (Fig. 1) [33]. High porosity assists nutrient and waste diffusion that is one of the critical factors for vascularization and tissue ingrowth [34, 35]. Additionally, porosity needs to be controlled for each application since an increase in porosity leads to a relative decrease in the mechanical properties [36]. The interconnection of the pores is also an important parameter that defines the effects of porosity and pore size [35, 37]. Given a scaffold with constant porosity, a decrease in the mean pore size will cause pore channels to narrow, which may inconvenience cell migration despite an increase in the surface area [38]. Relatively smaller pores and larger specific surface area assist cell attachment as shown in a study with collagen-glycosaminoglycan scaffolds that attachment of osteogenic cells was increased with decreasing mean pore size and increasing specific surface area [39]. Regarding the mobility of cells in a scaffold, it is not affected by the pore size alone, but also scaffolds' mechanical properties and adhesiveness [40]. Cell arrangement and morphology are influenced by scaffolds' architecture and topography [41], and it was shown that cell morphology has a role in the cell function [42-45]. Surface roughness may lead cells to have a round morphology while flat surfaces lead to an increased cell spreading [41]. Presence of aligned structures can facilitate cell alignment, for example, designing concave microgrooves in scaffolds can also be effective to align cells, and has implications in muscle tissue engineering by facilitating the formation of layered bundle tissues [46].

In a study with osteoblast-like cells, increased cell ingrowth was observed in the scaffolds with relatively smaller pores among the scaffolds with different mean pore sizes ranging from $100 \mu \mathrm{m}$ to $200 \mu \mathrm{m}$ [47]. In another study, a scaffold with gradually changing pore sizes from $88 \mu \mathrm{m}$ to $405 \mu \mathrm{m}$ was examined, and the pore range of 380-405 $\mu \mathrm{m}$ provided higher chondrocyte and osteoblast proliferation while the range between 186$200 \mu \mathrm{m}$ was more suitable for fibroblast proliferation [48]. On the other hand, new bone formation occurred faster in the scaffolds with the pore size range of 290 $310 \mu \mathrm{m}$ than in the other scaffolds [48]. Scaffolds with a mean pore size of $250 \mu \mathrm{m}$ had higher fibrous tissue ingrowth in vivo than that of other scaffolds with mean pore sizes of $30 \mu \mathrm{m}, 60 \mu \mathrm{m}, 110 \mu \mathrm{m}, 350 \mu \mathrm{m}$ and 700 $\mu \mathrm{m}$ [38]. The scaffolds with mean pore sizes of $30 \mu \mathrm{m}$ and $60 \mu \mathrm{m}$ had no tissue ingrowth even though pore sizes are larger than the size of a fibroblast [38]. The size of the pores can affect the osteogenic differentiation and proliferation of stem cells oppositely [49]. Ceramic scaffolds with a pore size of $200 \mu \mathrm{m}$ and $500 \mu \mathrm{m}$ were found to provide a relatively higher rate of osteogenic differentiation,

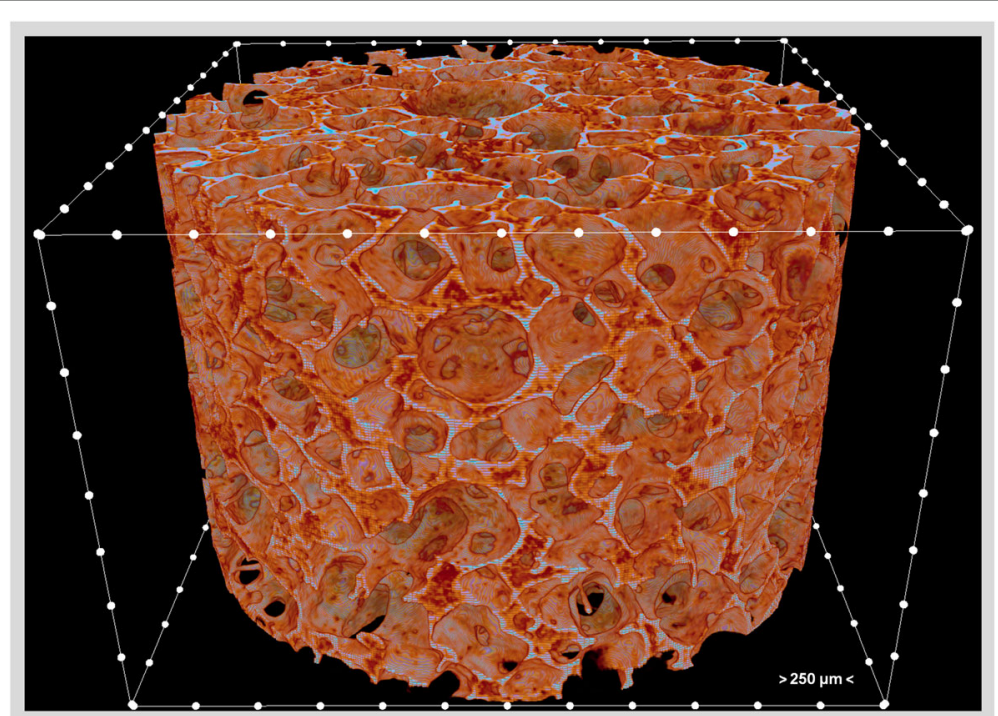

Fig. 1 A 3D micro-CT image of the polycaprolactone-polyurethane scaffold. The distance between two adjacent white dots is $250 \mu \mathrm{m}$ 
and proliferation, respectively, when compared to each other [49]. Both surface chemistry and pore size can significantly affect the lineage-specific differentiation of stem cells while the effect of surface chemistry found to be relatively larger if the pore size is smaller than $300 \mu \mathrm{m}$ [50].

Micro-CT characterization comprises three major sequential processes: acquisition, reconstruction, and analysis [13]. The X-rays are generated by the source and emitted to the target sample. When passing through the sample, the X-rays are attenuated based on the properties of a sample that is being scanned (e.g., its density, thickness, and composition). The acquisition is completed by collecting $2 \mathrm{D}$ projection images (radiographs) from many viewing angles. In the conventional micro-CT instruments, the X-ray system is fixed, and the sample stage rotates, while in the instruments for live small animals the stage is fixed, and the X-ray system rotates to scan the animal. The projection images are reconstructed by a computer using algorithms [51-53] to obtain the cross-sectional 2D images in the transverse plane (Fig. 2). Binarization is the process by which the pixels that belong to sample are discriminated in the reconstructed images that are in a contrast scale of $0-255$, and the images are made black and white (Fig. 3). Typically, white indicates the material while black indicates empty space. Volume, porosity, pore size, and suchlike results can be quantified using the binary image dataset. Commercial micro-CT instruments come with the manufacturers' software while an external software such as ImageJ (https://imagej.nih.gov/ij/index.html) could also be used.

Systematic search of the papers that were published in 2016 A systematic search was performed on the papers that were published in a predetermined year, 2016, to answer these questions: (i) what type of data was reported in the papers, i.e., quantitative or qualitative, or both, (ii) what kind of quantitative results were reported (such as microstructure (e.g., porosity, pore size, wall thickness), volume, and mineral density if relevant), and (iii) whether the reporting of the methods were adequate including the information on pixel size, number of replicates, rotation step or number of obtained projections, voltage and current values, and use of any filter). A search was performed on the electronic databases of Scopus, Web of Science, and PubMed using the term "micro-CT" with "scaffold" to identify the relevant original research papers in English that were published in 2016. The year 2016 was selected in the current work because it was presumed as a representative period. The papers that involve micro-CT characterization of scaffolds were considered as eligible. The papers were screened, selected as shown in the flowchart that is presented in Fig. 4, and analyzed to answer the aforementioned questions.

\section{Findings of the systematic search and discussion}

A total of 105 papers [54-158] were included in the systematic analysis. The data indicated that micro-CT was used only qualitatively in around $15 \%$ of the papers $[63,74,75,79,95,102,106,108,112,116,122,129$, $133,146,149,158]$, and only quantitatively in $9.5 \%$ of the papers [55, 78, 83, 85, 98, 111, 125, 131, 137, 155]. Micro-CT was used both qualitatively and quantitatively in the rest of the papers $[54,56-62,64-73,76$, 77, 80-82, 84, 86-94, 96, 97, 99-101, 103-105, 107, $109,110,113-115,117-121,123,124,126-128,130$, 132, 134-136, 138-145, 147, 148, 150-154, 156, 157]. Only around $29 \%$ of the papers reported the number of replicates (i.e., "n") they analyzed, and around $77 \%$ of the papers reported the used pixel size. Among the

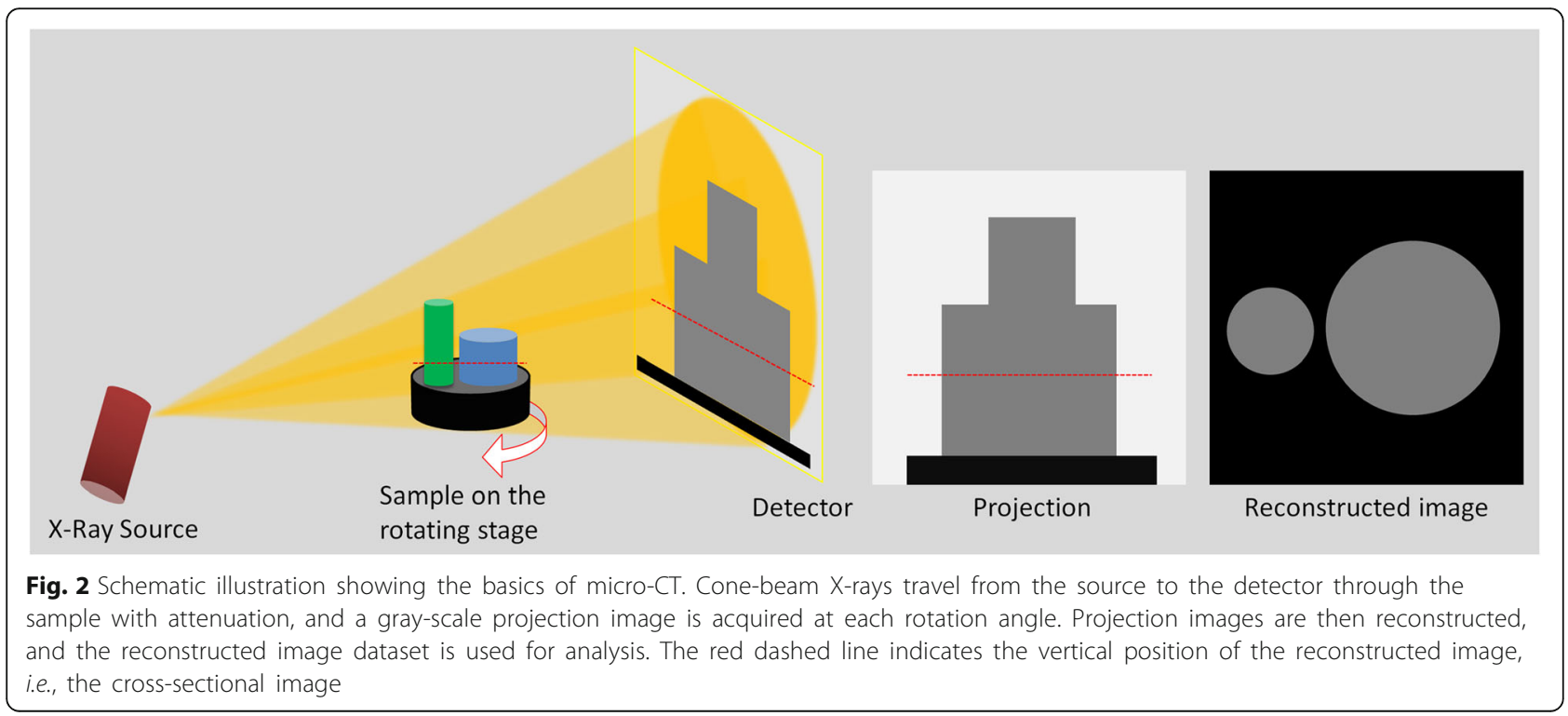




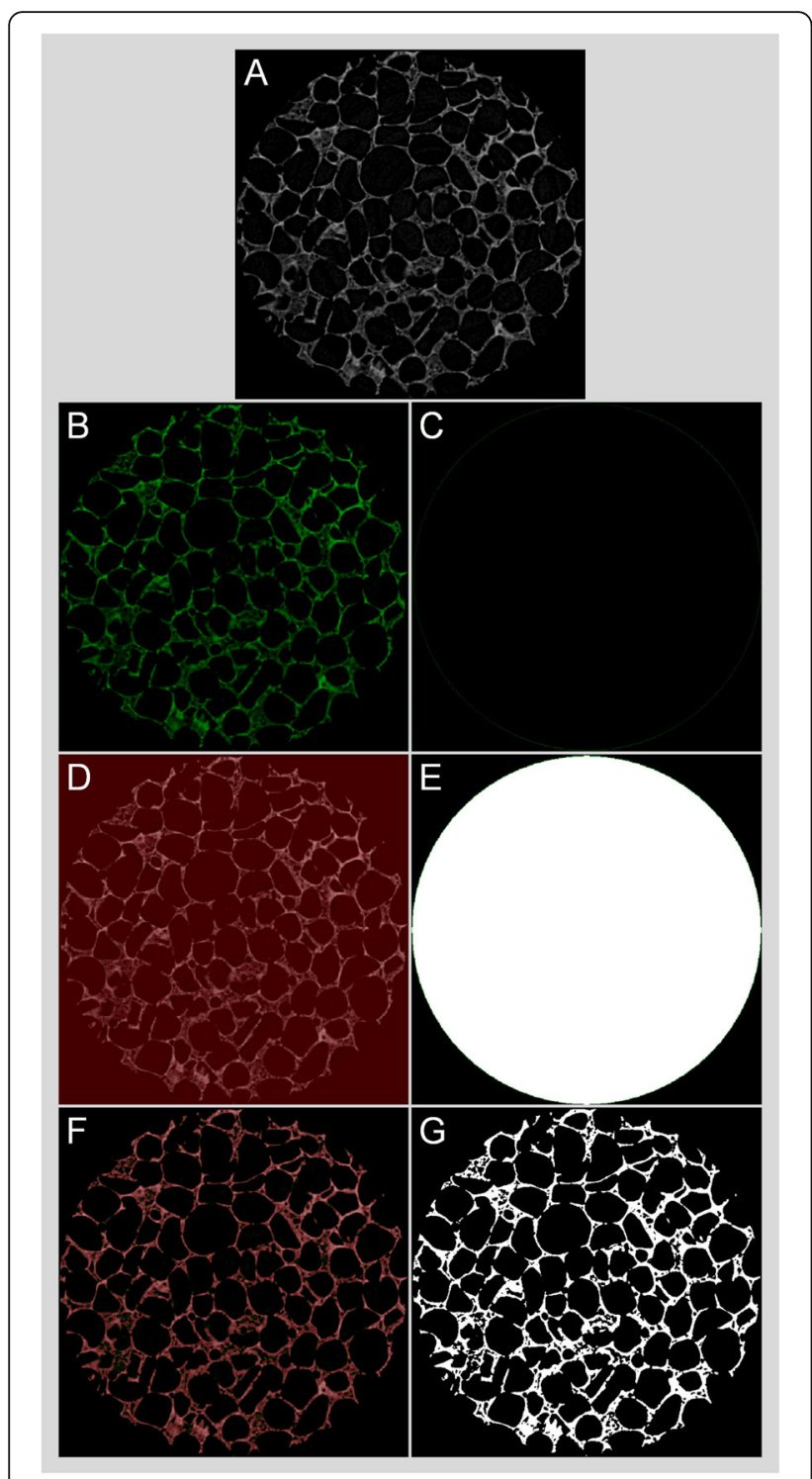

Fig. 3 Binarization of reconstructed micro- $C T$ images. Gray-scale reconstructed $2 \mathrm{D}$ image of a silk-based tissue engineering scaffold with a circular region of interest ( $\varnothing 3 \mathrm{~mm}$ ) (a), half-tone views $(\mathbf{b}, \mathbf{d}$, and $\mathbf{f}$ ) and the corresponding binary images ( $\mathbf{c}, \mathbf{e}$, and $\mathbf{g}$ ) respectively if no gray-scale value is included that yields to complete black, if entire gray-scale values are included that yields to complete white, and if the right gray-scale values (that is in this case 38-255) are obtained by global thresholding that yields to a binary image showing the microstructure of the scaffold

papers that reported $n$, the mean size of $n$ was 4.4 with a standard deviation (SD) of 2.8. The mean used pixel size was $16.8 \mu \mathrm{m}$ with an SD of 13.3. The analysis also showed that less than $3 \%$ of the papers used the term "spatial resolution", and around 14\% of the papers used the term "resolution" which might get confused with "pixel size" as it was discussed below. As Fig. 5 illustrates, volume measurements, microstructural characterization, and mineral density determination are the three most frequent quantitative results. The results categorized as "other" include histograms, area/distance measurements such as tissue thickness, bone contact area or graft diameter, callus index and intensity signals. The rotation step, or the number of obtained projections, is not mentioned in over $68 \%$ of the papers. The information on the used voltage and current was not reported in around $26 \%$ of the papers, while around $73 \%$ of the papers did not report whether they used a filter or not. One paper was identified that the term "in vivo imaging" was used when only explants were characterized.

The internal architecture of a scaffold has major roles in the cell behavior and thus on the overall performance of the construct, the characterization of its macro $(>100 \mu \mathrm{m})$ and micro $(0.1 \mu \mathrm{m}-100 \mu \mathrm{m})$ structure is inherently of interest. With the demonstrated use and advantages of micro-CT, it has been a valuable instrument in research laboratories with its challenges that are summarized in Table 1.

Micro-CT has been considered as the gold standard for bone explants' microstructure and morphology study [25]. In the case of scanning live animals, excessive exposure to radiation [159-161] can be a problem for the survival of the animal, tumorigenesis, and ethics. Using a pixel size less than $50 \mu \mathrm{m}$ may be fine to prevent excessive exposure to radiation [11].

From the results of this systematic analysis, two major points can be emphasized to be resolved in future studies that will use micro-CT: (i) methods section from acquisition to analysis should be complete, and (ii) information obtained should be maximized. The methods part should cover the used pixel size, voltage and current, number of replicates, scanning medium, use of any filter, rotation step/ number of projections, and use of any specific image processing. Various results can be derived from a Micro-CT characterization. These results can be quantitative or qualitative, and obtained in a $2 \mathrm{D}$ or $3 \mathrm{D}$ fashion. Qualitative results include X-ray and reconstructed image of the sample, mineral density color map, pores size color map, and structure thickness color map, and thus, provide valuable information. Quantitative results include quantification/ proportion of volumes, microstructural features (mean pore size, mean wall thickness, and their distribution and change vertically across the sample), mineral density, histograms, quantification of surface area, and surface:volume ratio. It should be noted that some of these parameters are relevant only for certain studies. For instance, bone mineral density is related only with scaffolds for bone tissue engineering. Therefore, this is a factor affecting the outcome of the systematic analysis.

CT experts may accept that resolution is a quite sensitive topic among authors by being a measure of image quality. As the outcome of the systematic analysis shows, some authors including some of the CT experts prefer to use terms "resolution" and "spatial resolution" instead 


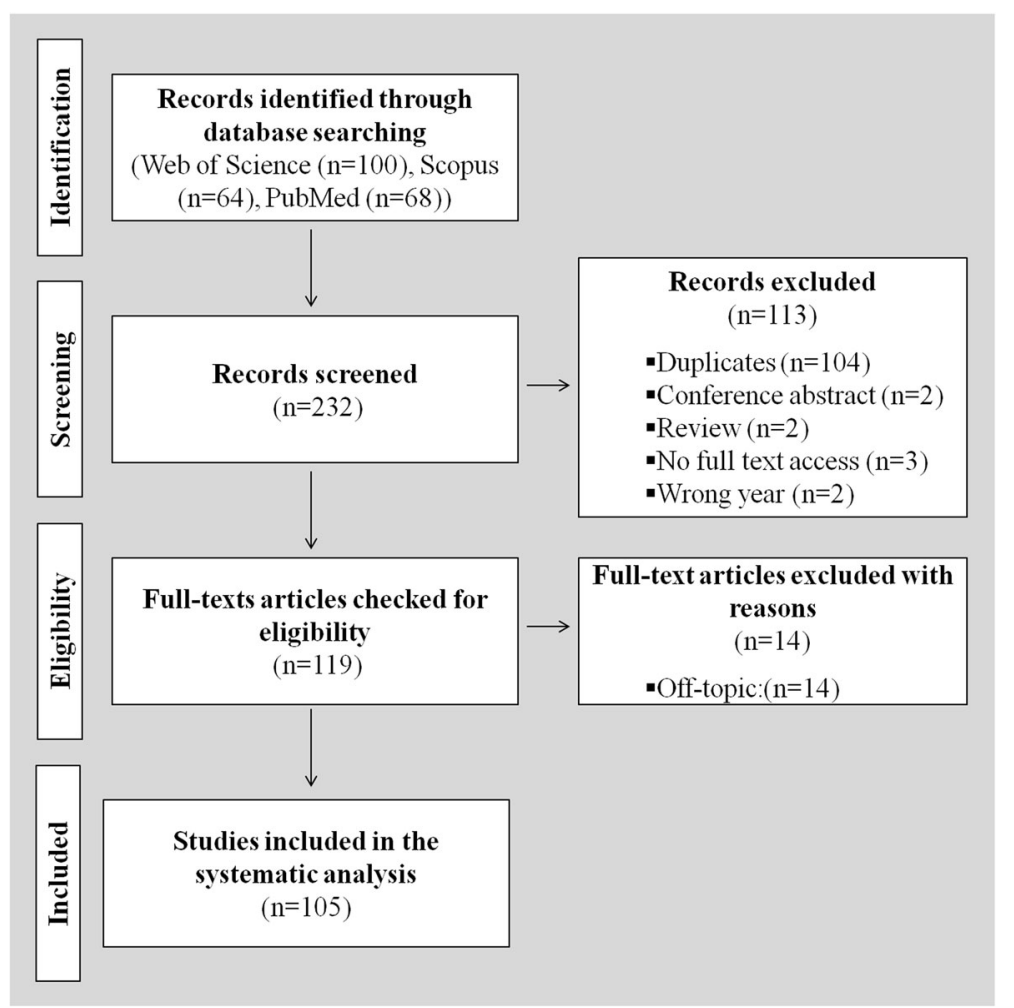

Fig. 4 The flowchart of the systematic search

of "pixel size" or "voxel size", while some micro-CT system manufacturers prefer to communicate the size of the pixels or voxel of the images. Additionally, there is no standardized approach for spatial resolution reporting accepted by the micro-CT system manufacturers [25]. The definitions of these terms are presented in Table 2.

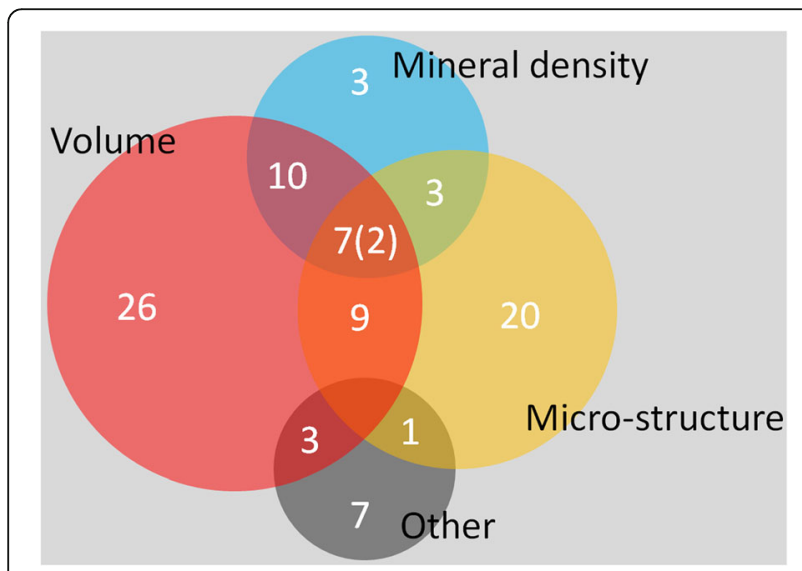

Fig. 5 Venn diagram showing the number of the papers that reported quantitative results regarding the volume, microstructure, mineral density and other measures. Two of the seven papers that reported volume, microstructure, and mineral density also reported additional results. The sizes of the circles in the diagrams are directly proportional to the number of the associated papers
The studies that report a value for resolution need to show how they quantify the resolution whether it is the pixel size given by the scanner software or they quantified it with calibrated thickness wires [162]. Given the definitions of the terms, the images that have the same number of pixels would contain different information if their pixel sizes are not identical. It is noteworthy to know that a smaller pixel size does not necessarily provide a better image, for instance, the image does not improve when the pixel size is smaller than the X-ray spot size $[162,163]$. Some other factors $[25,162,164,165]$ are needed to be considered as well, regarding X-ray (e.g., energy, geometry, and focal-spot size), sensitivity of detector, use of filter, integration time of X-ray with the sample per projection, characteristics of the sample (e.g., composition and size), scanning medium, noise and artifacts. The attenuation of the X-rays depends on the characteristics of the sample such as its density and thickness. The level of the X-ray energy, i.e., the source voltage and current, should be tuned for the sample (denser samples require higher energy) since the obtained the images are in gray-scale and associated with the X-ray absorption that is linked with the sample's electron density [163]. Therefore, the reconstructed images are quantitatively densitometric. The pixel size and rotation step can have significant influences on the quantitative and qualitative results of the $\mu$-CT characterization of scaffolds, as well as the size of 
Table 1 Challenges in the conventional micro-CT characterization

\begin{tabular}{|c|c|c|}
\hline Challenge & Potential solution & Reference \\
\hline Artifacts and noise. & Detailed in Table 1 of Ref. [162] & {$[162,164,169,170]$} \\
\hline $\begin{array}{l}\text { Soft tissue characterization is not as easy as a dry-state } \\
\text { porous scaffold. }\end{array}$ & $\begin{array}{l}\text { Using contrast agents or high-atomic-number } \\
\text { element probes can help. }\end{array}$ & [28-32] \\
\hline $\begin{array}{l}\text { Operator-determined acquisition parameters may affect } \\
\text { the results. }\end{array}$ & $\begin{array}{l}\text { Parameters should be optimized during the } \\
\text { preliminary study. }\end{array}$ & [13] \\
\hline $\begin{array}{l}\text { Harsh acquisitions may damage/alter the sample/tissue } \\
\text { (for example, discoloring of a biomaterial or tumorigenesis } \\
\text { in animals); and radiation exposure of animals in live } \\
\text { animal studies, lethal dose } 50 / 30 \text { (both ethical and scientific } \\
\text { considerations). }\end{array}$ & $\begin{array}{l}\text { Long scans (either due to very low rotation step, } \\
\text { frame averaging, or long exposure time) should be } \\
\text { avoided, and/or X-ray energy could be decreased. }\end{array}$ & {$[11,159-161]$} \\
\hline $\begin{array}{l}\text { Comparing micro- } \mathrm{CT} \text { results of different studies is not easy } \\
\text { if the used parameters are not identical. }\end{array}$ & $\begin{array}{l}\text { There is a need to establish a protocol with } \\
\text { determined values for parameters. }\end{array}$ & [13] \\
\hline $\begin{array}{l}\text { Issues with very dense/thick samples resulting in a dataset } \\
\text { of almost only black images. }\end{array}$ & $\begin{array}{l}\text { This is because there will be no contrast since } \\
\text { no X-ray can pass; however, use of a filter may } \\
\text { resolve the problem, but it may greatly increase } \\
\text { the acquisition time. The sample can be cut to } \\
\text { its smaller representative volume. If it is not } \\
\text { possible, then another instrument could be used } \\
\text { such as a scanning electron microscope. }\end{array}$ & \\
\hline $\begin{array}{l}\text { Issues with very thin/light samples or a hydrogel, then no } \\
\text { contrast will be obtained (this gives a dataset of images } \\
\text { with very low contrast). }\end{array}$ & Contrast agents can be used. & [29-32] \\
\hline $\begin{array}{l}\text { A limited volume of sample that can be analyzed at once } \\
\text { (the images have a certain number of pixels with a certain } \\
\text { size of a pixel). }\end{array}$ & $\begin{array}{l}\text { Display matrix size and/or pixel size can be } \\
\text { adapted. The representative portion of the } \\
\text { sample can be pre-determined. }\end{array}$ & \\
\hline $\begin{array}{l}\text { Overlaps in gray-scale values in multi-material samples } \\
\text { (i.e., scaffold-bone explants or composites). }\end{array}$ & Advanced segmentation protocol can be used. & [171] \\
\hline Considerations on the maintenance and sharing of micro- $\mathrm{CT}$ data. & $\begin{array}{l}\text { During the preliminary study, the duration of the } \\
\text { micro-CT characterization and the disc space } \\
\text { requirements can be estimated. }\end{array}$ & [13] \\
\hline
\end{tabular}

Table 2 Terms that are associated with the micro-CT images, and their definitions

\begin{tabular}{ll}
\hline Term & Definition \\
\hline Pixel size & Size of the 2D discrete parts that make up a 2D \\
& micro-CT image. Usually, expressed as a single \\
& value, e.g., $10 \mu \mathrm{m}$, indicating the size of each \\
& pixel is $10 \mu \mathrm{m} \times 10 \mu \mathrm{m}$.
\end{tabular}

the generated data and the duration of the characterization [13]. Integration time is the duration of each projection. A longer integration time provides more photos to be detected and affect the micro-CT image [166]. The use of a filter can improve the characterization of thick/dense samples by attenuating the low-energy $\mathrm{X}$-rays and minimizing the beam hardening effect [25]. Spatial resolution depends on the geometry of the X-ray, and detector [10]. Cone beam X-rays and flat panel detectors provide significantly shorter scanning times because the data for multiple slices is obtained in each rotation step, while fan beam X-rays and linear detectors provide less scatter effects for thick samples [167] and higher accuracy [164]. Reconstruction method also depends on the geometry of the source. The scanning medium (e.g., air, water, phosphate-buffered saline, or ethanol) influences the characterization results since different media affect the X-ray attenuation differently [25, 168].

\section{Conclusion}

The microstructure of tissue engineering scaffolds greatly influence the behavior of cells, and the performance of the tissue engineering construct; therefore, the characterization of the scaffolds' microstructure is of 
keen interest. Micro-CT is an outstanding instrument for the quantitative $2 \mathrm{D}$ and $3 \mathrm{D}$ analysis and visualization of scaffolds. The analysis results showed that the methods sections of the majority of the analyzed papers are in need of improvement in reporting the details of micro-CT characterization. Moreover, the amount of quantitative and qualitative information from micro-CT characterization can be maximized. Given the fact that the obtained results from micro-CT characterization significantly depend on several parameters, the important acquisition related details should be clearly provided in the papers. It is recommended that the parameters include the used pixel size, rotation step, X-ray energy, scanning medium, use of filter, as well as the number of samples analyzed since the omitted data complicate the reproducibility of the experiments.

\section{Acknowledgments}

This work is a result of the project FROnTHERA (NORTE-01-0145-FEDER-000023) supported by the Norte Portugal Regional Operational Programme (NORTE 2020) under the Portugal 2020 Partnership Agreement, through European Regional Development Fund (ERDF). IFC thanks the Portuguese Foundation for Science and Technology (FCT) for the Ph.D. scholarship (SFRH/BD/99555/2014). $\mathrm{JMO}$ also thanks the FCT for the funds provided under the program Investigador FCT 2012 and 2015 (IF/00423/2012 and IF/01285/2015).

\section{Funding}

FROnTHERA Project (NORTE-01-0145-FEDER-000023) within the Norte Portugal Regional Operational Programme (NORTE 2020) under the Portugal 2020 Partnership Agreement, through ERDF, and Portuguese Foundation for Science and Technology (SFRH/BD/99555/2014, IF/00423/2012, and IF/01285/2015).

\section{Author's contributions}

All authors wrote and revised the manuscript. All authors read and approved the final manuscript.

Ethics approval and consent to participate

Not applicable.

\section{Consent for publication}

Not applicable.

\section{Competing interests}

The authors declare that they have no competing interests.

\section{Publisher's Note}

Springer Nature remains neutral with regard to jurisdictional claims in published maps and institutional affiliations.

\footnotetext{
Author details

'3B's Research Group, I3Bs - Research Institute on Biomaterials, Biodegradables and Biomimetics, University of Minho, Headquarters of the European Institute of Excellence on Tissue Engineering and Regenerative Medicine, AvePark, Parque de Ciência e Tecnologia, Zona Industrial da Gandra, Barco, 4805-017 Guimarães, Portugal. ${ }^{2} I C V S / 3 B$ 's - PT Government Associate Laboratory, Braga/Guimarães, Portugal. ${ }^{3}$ The Discoveries Centre for Regenerative and Precision Medicine, Headquarters at University of Minho, AvePark, Parque de Ciência e Tecnologia, Zona Industrial da Gandra, Barco, 4805-017 Guimarães, Portugal.
}

Received: 12 June 2018 Accepted: 3 September 2018 Published online: 26 September 2018

\section{References}

1. Wegst UG, Bai H, Saiz E, Tomsia AP, Ritchie RO. Bioinspired structural materials. Nat Mater. 2015;14(1):23-36.
2. Lee J, Cuddihy MJ, Kotov NA. Three-dimensional cell culture matrices: State of the art. Tissue Eng Part B-Re. 2008;14(1):61-86.

3. Baker BM, Chen CS. Deconstructing the third dimension - How 3D culture microenvironments alter cellular cues. J Cell Sci. 2012;125(13):3015-24.

4. Cengiz IF, Pereira H, de Girolamo L, Cucchiarini M, Espregueira-Mendes J, Reis RL. Oliveira JM Orthopaedic regenerative tissue engineering en route to the holy grail: disequilibrium between the demand and the supply in the operating room. J Exp Orthop. 2018;5(1):14.

5. Chew SY, Low WC. Scaffold-based approach to direct stem cell neural and cardiovascular differentiation: An analysis of physical and biochemical effects. J Biomed Mater Res A. 2011;97(3):355-74.

6. Kim K, Yeatts A, Dean D, Fisher JP. Stereolithographic bone scaffold design parameters: Osteogenic differentiation and signal expression. Tissue Eng Part B-Re. 2010;16(5):523-39.

7. Yamamoto M, Rafii S, Rabbany SY. Scaffold biomaterials for nanopathophysiology. Adv Drug Del Rev. 2014;74:104-14.

8. Zhang B, Xiao Y, Hsieh A, Thavandiran N, Radisic M. Micro-and nanotechnology in cardiovascular tissue engineering. Nanotechnology. 2011;22(49):494003.

9. Cengiz IF, Pereira H, Espregueira-Mendes J, Oliveira JM, Reis RL. Treatments of meniscus lesions of the knee: Current concepts and future perspectives. Regen Eng Transl Med. 2017;3(1):1-19.

10. Landis EN. Keane DT X-ray microtomography. Mater Charact. 2010;61(12): 1305-16.

11. Ritman EL. Micro-computed tomography - Current status and developments. Annu Rev Biomed Eng. 2004;6:185-208.

12. Cengiz IF, Pitikakis M, Cesario L, Parascandolo P, Vosilla L, Viano G, Oliveira J, Reis R. Building the basis for patient-specific meniscal scaffolds: From human knee MRI to fabrication of 3D printed scaffolds. Bioprinting. 2016;1:1-10.

13. Cengiz IF, Oliveira JM, Reis RL. Micro-computed tomography characterization of tissue engineering scaffolds: Effects of pixel size and rotation step. J Mater Sci Mater Med. 2017;28(8):129.

14. Ho ST, Hutmacher DW. A comparison of micro-CT with other techniques used in the characterization of scaffolds. Biomaterials. 2006;27(8):1362-76.

15. Jones AC, Arns CH, Sheppard AP, Hutmacher DW, Milthorpe BK, Knackstedt MA. Assessment of bone ingrowth into porous biomaterials using Micro-CT. Biomaterials. 2007;28(15):2491-504.

16. Lienemann PS, Metzger S, Kiveliö A-S, Blanc A, Papageorgiou P, Astolfo A, Pinzer BR, Cinelli P, Weber FE, Schibli R. Longitudinal in vivo evaluation of bone regeneration by combined measurement of multipinhole SPECT and micro-CT for tissue engineering. Scientific Reports. 2015;5:10238.

17. Luu Y, Lublinsky S, Ozcivici E, Capilla E, Pessin J, Rubin C, Judex S. In vivo quantification of subcutaneous and visceral adiposity by micro-computed tomography in a small animal model. Med Eng Phys. 2009;31(1):34-41.

18. Paulus MJ, Gleason SS, Kennel SJ, Hunsicker PR, Johnson DK. High resolution $X$-ray computed tomography: An emerging tool for small animal cancer research. Neoplasia. 2000;2(1-2):62-70.

19. Waarsing J, Day J, Van der Linden J, Ederveen A, Spanjers C, De Clerck N, Sasov A, Verhaar J, Weinans H. Detecting and tracking local changes in the tibiae of individual rats: A novel method to analyse longitudinal in vivo micro-CT data. Bone. 2004;34(1):163-9.

20. Birkhold Al, Razi H, Weinkamer R, Duda GN, Checa S, Willie BM. Monitoring in vivo (re) modeling: A computational approach using $4 \mathrm{D}$ microCT data to quantify bone surface movements. Bone. 2015;75:210-21.

21. Hildebrand T, Laib A, Müller R, Dequeker J, Rüegsegger P. Direct threedimensional morphometric analysis of human cancellous bone: Microstructural data from spine, femur, iliac crest, and calcaneus. J Bone Miner Res. 1999;14(7):1167-74.

22. Pereira H, Caridade S, Frias A, Silva-Correia J, Pereira D, Cengiz IF, Mano J, Oliveira JM, Espregueira-Mendes J, Reis R. Biomechanical and cellular segmental characterization of human meniscus: Building the basis for Tissue Engineering therapies. Osteoarthritis Cartilage. 2014;22(9):1271-81.

23. Batiste DL, Kirkley A, Laverty S, Thain LM, Spouge AR, Holdsworth DW. Ex vivo characterization of articular cartilage and bone lesions in a rabbit $\mathrm{ACL}$ transection model of osteoarthritis using MRI and micro-CT. Osteoarthritis Cartilage. 2004;12(12):986-96.

24. Bentley MD, Ortiz MC, Ritman EL, Romero JC. The use of microcomputed tomography to study microvasculature in small rodents. Am J Physiol Regul Integr Comp Physiol. 2002;282(5):R1267-R79. 
25. Bouxsein ML, Boyd SK, Christiansen BA, Guldberg RE, Jepsen KJ, Müller R. Guidelines for assessment of bone microstructure in rodents using microcomputed tomography. J Bone Miner Res. 2010;25(7):1468-86.

26. Cardeira J, Gavaia PJ, Fernández I, Cengiz IF, Moreira-Silva J, Oliveira JM, Reis RL, Cancela ML, Laizé V. Quantitative assessment of the regenerative and mineralogenic performances of the zebrafish caudal fin. Scientific Reports. 2016;6:39191.

27. Layton MW, Goldstein SA, Goulet RW, Feldkamp LA, Kubinski DJ, Bole GG. Examination of subchondral bone architecture in experimental osteoarthritis by microscopic computed axial tomography. Arthritis Rheumatol. 1988; 31(11):1400-5.

28. Mizutani R, Suzuki Y. X-ray microtomography in biology. Micron. 2012; 43(2):104-15.

29. Lusic H, Grinstaff MW. X-ray-computed tomography contrast agents. Chem Rev. 2012;113(3):1641-66.

30. Pauwels E, Van Loo D, Cornillie P, Brabant L, Van Hoorebeke L. An exploratory study of contrast agents for soft tissue visualization by means of high resolution X-ray computed tomography imaging. J Microsc. 2013; 250(1):21-31.

31. Xing R, Wilde D, McCann G, Ridwan Y, Schrauwen JT, Steen AF, Gijsen FJ, Heiden K. Contrast-enhanced micro-CT imaging in murine carotid arteries: A new protocol for computing wall shear stress. Biomed Eng Online. 2016; 15(2):156.

32. Young S, Kretlow JD, Nguyen C, Bashoura AG, Baggett LS, Jansen JA, Wong M, Mikos AG. Microcomputed tomography characterization of neovascularization in bone tissue engineering applications. Tissue Eng Part B-Re. 2008;14(3):295-306.

33. Yang S, Leong K-F, Du Z, Chua C-K. The design of scaffolds for use in tissue engineering. Part I. Traditional factors. Tissue Eng. 2001;7(6):679-89.

34. Karande TS, Ong JL, Agrawal CM. Diffusion in musculoskeletal tissue engineering scaffolds: Design issues related to porosity, permeability, architecture, and nutrient mixing. Ann Biomed Eng. 2004;32(12):1728-43.

35. Mastrogiacomo M, Scaglione S, Martinetti R, Dolcini L, Beltrame F, Cancedda R, Quarto R. Role of scaffold internal structure on in vivo bone formation in macroporous calcium phosphate bioceramics. Biomaterials. 2006:27(17):3230-7.

36. Karageorgiou V, Kaplan D. Porosity of $3 \mathrm{D}$ biomaterial scaffolds and osteogenesis. Biomaterials. 2005;26(27):5474-91.

37. Freyman T, Yannas I, Gibson L. Cellular materials as porous scaffolds for tissue engineering. Prog Mater Sci. 2001;46(3):273-82

38. Yamamoto M, Tabata Y, Kawasaki H, Ikada Y. Promotion of fibrovascular tissue ingrowth into porous sponges by basic fibroblast growth factor. J Mater Sci Mater Med. 2000;11(4):213-8.

39. O'Brien FJ, Harley B, Yannas IV, Gibson LJ. The effect of pore size on cell adhesion in collagen-GAG scaffolds. Biomaterials. 2005;26(4):433-41.

40. Peyton SR, Kalcioglu ZI, Cohen JC, Runkle AP, Van Vliet KJ, Lauffenburger DA, Griffith LG. Marrow-derived stem cell motility in 3D synthetic scaffold is governed by geometry along with adhesivity and stiffness. Biotechnol Bioeng. 2011:108(5):1181-93.

41. Clegg JR, Wechsler ME, Peppas NA. Vision for functionally decorated and molecularly imprinted polymers in regenerative engineering. Regen Eng Transl Med. 2017;3(3):166-75.

42. Folkman J, Moscona A. Role of cell shape in growth control. Nature. 1978; 273(5661):345

43. Kumar G, Tison CK, Chatterjee K, Pine PS, McDaniel JH, Salit ML, Young MF, Simon CG Jr. The determination of stem cell fate by 3D scaffold structures through the control of cell shape. Biomaterials. 2011;32(35): 9188-96.

44. Kumar G, Waters MS, Farooque TM, Young MF, Simon CG Jr. Freeform fabricated scaffolds with roughened struts that enhance both stem cell proliferation and differentiation by controlling cell shape. Biomaterials. 2012; 33(16):4022-30.

45. McBeath R, Pirone DM, Nelson CM, Bhadriraju K, Chen CS. Cell shape, cytoskeletal tension, and RhoA regulate stem cell lineage commitment. Dev Cell. 2004;6(4):483-95.

46. Chen S, Nakamoto T, Kawazoe N, Chen G. Engineering multi-layered skeletal muscle tissue by using 3D microgrooved collagen scaffolds. Biomaterials. 2015;73:23-31

47. Chen J, Paetzell E, Zhou J, Lyons L, Soboyejo W. Osteoblast-like cell ingrowth, adhesion and proliferation on porous Ti-6Al-4V with particulate and fiber scaffolds. Mater Sci Eng, C. 2010;30(5):647-56.
48. Oh SH, Park IK, Kim JM, Lee JH. In vitro and in vivo characteristics of PCL scaffolds with pore size gradient fabricated by a centrifugation method. Biomaterials. 2007;28(9):1664-71.

49. Mygind T, Stiehler M, Baatrup A, Li H, Zou X, Flyvbjerg A, Kassem M, Bünger C. Mesenchymal stem cell ingrowth and differentiation on coralline hydroxyapatite scaffolds. Biomaterials. 2007;28(6):1036-47.

50. Zhao Y, Tan K, Zhou Y, Ye Z, Tan W-S. A combinatorial variation in surface chemistry and pore size of three-dimensional porous poly ( $\varepsilon$-caprolactone) scaffolds modulates the behaviors of mesenchymal stem cells. Mater Sci Eng, C. 2016;59:193-202.

51. Faridani A. Results, old and new, in computed tomography. In: Inverse Problems in Wave Propagation. New York: Springer; 1997. p. 167-93.

52. Feldkamp L, Davis L. Kress J Practical cone-beam algorithm. JOSA A. 1984; 1(6):612-9.

53. Gordon R, Herman G. Three-dimensional reconstruction from projections: A review of algorithms. Int Rev Cytol. 1974;38:111-51.

54. Adamzyk C, Kachel P, Hoss M, Gremse F, Modabber A, Hölzle F, Tolba R, Neuss S, Lethaus B. Bone tissue engineering using polyetherketoneketone scaffolds combined with autologous mesenchymal stem cells in a sheep calvarial defect model. J Craniomaxillofac Surg. 2016;44(8):985-94.

55. Almela T, Brook IM, Moharamzadeh K. Development of three-dimensional tissue engineered bone-oral mucosal composite models. J Mater Sci Mater Med. 2016;27(4):65.

56. Altamura D, Pastore SG, Raucci MG, Siliqi D, De Pascalis F, Nacucchi M, Ambrosio L, Giannini C. Scanning small-and wide-angle X-ray scattering microscopy selectively probes ha content in gelatin/hydroxyapatite scaffolds for osteochondral defect repair. ACS Appl Mater Inter. 2016;8(13): 8728-36.

57. Amini AR, Xu TO, Chidambaram RM, Nukavarapu SP. Oxygen tensioncontrolled matrices with osteogenic and vasculogenic cells for vascularized bone regeneration in vivo. Tissue Eng Pt A. 2016;22(7-8):610-20.

58. Arabnejad S, Johnston RB, Pura JA, Singh B, Tanzer M, Pasini D. Highstrength porous biomaterials for bone replacement: A strategy to assess the interplay between cell morphology, mechanical properties, bone ingrowth and manufacturing constraints. Acta Biomater. 2016;30:345-56.

59. Araujo-Pires AC, Mendes VC, Ferreira-Junior O, Carvalho PSP, Guan L, Davies JE. Investigation of a novel PLGA/CaP scaffold in the healing of tooth extraction sockets to alveolar bone preservation in humans. Clin Implant Dent R. 2016;18(3):559-70.

60. Arifvianto $B$, Leeflang $M$, Zhou J. Characterization of the porous structures of the green body and sintered biomedical titanium scaffolds with microcomputed tomography. Mater Charact. 2016;121:48-60.

61. Barui S, Chatterjee S, Mandal S, Kumar A, Basu B. Microstructure and compression properties of 3D powder printed Ti-6Al-4V scaffolds with designed porosity: Experimental and computational analysis. Mater Sci Eng, C. 2017;70:812-23.

62. Beck A, Murphy DJ, Carey-Smith R, Wood DJ, Zheng MH. Treatment of articular cartilage defects with microfracture and autologous matrix-induced chondrogenesis leads to extensive subchondral bone cyst formation in a sheep model. Am J Sport Med. 2016:44(10):2629-43.

63. Bolaños RV, Cokelaere S, McDermott JE, Benders K, Gbureck U, Plomp S, Weinans $H$, Groll J, van Weeren P, Malda J. The use of a cartilage decellularized matrix scaffold for the repair of osteochondral defects: The importance of long-term studies in a large animal model. Osteoarthr Cartil. 2017:25(3):413-20.

64. Carlisle PL, Guda T, Silliman DT, Lien W, Hale RG, Brown Baer PR. Investigation of a pre-clinical mandibular bone notch defect model in miniature pigs: Clinical computed tomography, micro-computed tomography, and histological evaluation. J Korean Assoc Oral Maxillofac Surg. 2016;42(1):20-30.

65. Chamieh F, Collignon A-M, Coyac BR, Lesieur J, Ribes S, Sadoine J, Llorens A Nicoletti A, Letourneur D, Colombier M-L. Accelerated craniofacial bone regeneration through dense collagen gel scaffolds seeded with dental pulp stem cells. Sci Rep. 2016:6:38814.

66. Chandran S, Babu SS, Varma H, John A. Osteogenic efficacy of strontium hydroxyapatite micro-granules in osteoporotic rat model. J Biomater Appl. 2016;31(4):499-509.

67. Chang B, Song W, Han T, Yan J, Li F, Zhao L, Kou H, Zhang Y. Influence of pore size of porous titanium fabricated by vacuum diffusion bonding of titanium meshes on cell penetration and bone ingrowth. Acta Biomater. 2016:33:311-21. 
68. Chang Y-L, Lo Y-J, Feng S-W, Huang Y-C, Tsai H-Y, Lin C-T, Fan K-H, Huang $\mathrm{H}-\mathrm{M}$. Bone healing improvements using hyaluronic acid and hydroxyapatite/beta-tricalcium phosphate in combination: an animal study. BioMed Res Int. 2016;2016:8301624.

69. Chen G, Yang L, Lv Y. Cell-free scaffolds with different stiffness but same microstructure promote bone regeneration in rabbit large bone defect model. J Biomed Mater Res A. 2016;104(4):833-41.

70. Costantini M, Colosi C, Mozetic P, Jaroszewicz J, Tosato A, Rainer A, Trombetta M, Święszkowski W, Dentini M, Barbetta A. Correlation between porous texture and cell seeding efficiency of gas foaming and microfluidic foaming scaffolds. Mater Sci Eng, C. 2016;62:668-77.

71. Crica LE, Wengenroth J, Tiainen H, Ionita M, Haugen HJ. Enhanced X-ray absorption for micro-CT analysis of low density polymers. J Biomater Sci Polym Ed. 2016;27(9):805-23.

72. Cui W, Sun G, Qu Y, Xiong Y, Sun T, Ji Y, Yang L, Shao Z, Ma J, Zhang S. Repair of rat calvarial defects using Si-doped hydroxyapatite scaffolds loaded with a bone morphogenetic protein-2-related peptide. J Orth Res. 2016;34(11):1874-82.

73. Ding M, Henriksen SS, Theilgaard N, Overgaard S. Assessment of activated porous granules on implant fixation and early bone formation in sheep. $J$ Orthop Transl. 2016;5:38-47.

74. Dumont VC, Mansur AA, Carvalho SM, Borsagli FGM, Pereira MM, Mansur HS. Chitosan and carboxymethyl-chitosan capping ligands: Effects on the nucleation and growth of hydroxyapatite nanoparticles for producing biocomposite membranes. Mater Sci Eng, C. 2016;59:265-77.

75. Dumont VC, Mansur HS, Mansur AA, Carvalho SM, Capanema NS, Barrioni BR. Glycol chitosan/nanohydroxyapatite biocomposites for potential bone tissue engineering and regenerative medicine. Int J Biol Macromol. 2016;93:1465-78.

76. Erdogan O, Supachawaroj N, Soontornvipart K, Kheolamai P. Treatment of peri-implant defects in the rabbit's tibia with adipose or bone marrowderived mesenchymal stems cells. Clin Implant Dent R. 2016;18(5):1003-14.

77. Fang X, Xie J, Zhong L, Li J, Rong D, Li X, Ouyang J. Biomimetic gelatin methacrylamide hydrogel scaffolds for bone tissue engineering. J Mater Chem B. 2016;4(6):1070-80.

78. Fortier LA, Chapman HS, Pownder SL, Roller BL, Cross JA, Cook JL, Cole BJ. BioCartilage improves cartilage repair compared with microfracture alone in an equine model of full-thickness cartilage loss. Am J Sport Med. 2016;44(9):2366-74.

79. Frohbergh ME, Guevara JM, Grelsamer RP, Barbe MF, He X, Simonaro CM, Schuchman EH. Acid ceramidase treatment enhances the outcome of autologous chondrocyte implantation in a rat osteochondral defect model. Osteoarthr Cartil. 2016;24(4):752-62.

80. Geng H, Todd NM, Devlin-Mullin A, Poologasundarampillai G, Kim TB, Mad K, Cartmell S, Mitchell CA, Jones JR, Lee PD. A correlative imaging based methodology for accurate quantitative assessment of bone formation in additive manufactured implants. J Mater Sci Mater Med. 2016;27(6):112.

81. Giuliani A, Manescu A, Mohammadi S, Mazzoni S, Piattelli A, Mangano F, lezzi G, Mangano C. Quantitative kinetics evaluation of blocks versus granules of biphasic calcium phosphate scaffolds (HA/ $\beta-T C P$ 30/70) by synchrotron radiation X-ray microtomography: A human study. Implant Dent. 2016;25(1):6-15.

82. Gong W, Lei D, Li S, Huang P, Qi Q, Sun Y, Zhang Y, Wang Z, You Z, Ye X Hybrid small-diameter vascular grafts: Anti-expansion effect of electrospun poly $\varepsilon$-caprolactone on heparin-coated decellularized matrices. Biomaterials. 2016;76:359-70

83. Goodrich LR, Chen AC, Werpy NM, Williams AA, Kisiday JD, Su AW, Cory E, Morley PS, Mcllwraith CW, Sah RL. Addition of mesenchymal stem cells to autologous platelet-enhanced fibrin scaffolds in chondral defects: Does it enhance repair? J Bone Joint Surg Am. 2016;98(1):23.

84. Hassana OB, Guessasma S, Belhabib S, Nouri H. Explaining the difference between real part and virtual design of 3D printed porous polymer at the microstructural level. Macromol Mater Eng. 2016;301(5):566-76.

85. He S, Lin KF, Sun Z, Song Y, Zhao YN, Wang Z, Bi L, Liu J. Effects of Nanohydroxyapatite/poly (dl-lactic-co-glycolic acid) Microsphere-based Composite Scaffolds on Repair of Bone Defects: Evaluating the Role of Nano-hydroxyapatite Content. Artif Organs. 2016;40(7):128-35.

86. Hirota M, Shima T, Sato I, Ozawa T, Iwai T, Ametani A, Sato M, Noishiki Y, Ogawa T, Hayakawa T. Development of a biointegrated mandibular reconstruction device consisting of bone compatible titanium fiber mesh scaffold. Biomaterials. 2016;75:223-36.
87. Huang X, Li Y, Xu J, Liu K, Yu X, Cheng X, Xu D, Li Z. Restoration of murine femoral segmental defect using CTGF-overexpressing MC3T3-E1 cells. Am J Transl Res. 2016;8(3):1530.

88. Huynh NC-N, Everts V, Nifuji A, Pavasant P, Ampornaramveth RS. Histone deacetylase inhibition enhances in-vivo bone regeneration induced by human periodontal ligament cells. Bone. 2017;95:76-84.

89. Hwang PT, Lim D-J, Fee T, Alexander GC, Tambralli A, Andukuri A, Tian L, Cui W, Berry J, Gilbert SR. A bio-inspired hybrid nanosack for graft vascularization at the omentum. Acta Biomater. 2016;41:224-34.

90. Jang JY, Park SH, Park JH, Lee BK, Yun J-H, Lee B, Kim JH, Min BH, Kim MS. In vivo osteogenic differentiation of human dental pulp stem cells embedded in an injectable in vivo-forming hydrogel. Macromol Biosci. 2016;16(8):1158-69.

91. Jaroszewicz J, Kosowska A, Hutmacher D, Swieszkowski W, Moskalewski S. Insight into characteristic features of cartilage growth plate as a physiological template for bone formation. J Biomed Mater Res A. 2016; 104(2):357-66.

92. Jia P, Chen H, Kang H, Qi J, Zhao P, Jiang M, Guo L, Zhou Q, Qian ND, Zhou HB. Deferoxamine released from poly (lactic-co-glycolic acid) promotes healing of osteoporotic bone defect via enhanced angiogenesis and osteogenesis. J Biomed Mater Res A. 2016;104(10):2515-27.

93. John L, Janeta M, Rajczakowska M, Ejfler J, Lydzba D, Szafert S. Synthesis and microstructural properties of the scaffold based on a 3-(trimethoxysilyl) propyl methacrylate-POSS hybrid towards potential tissue engineering applications. RSC Advances. 2016;6(70):66037-47.

94. Kerckhofs G, Chai Y, Luyten F, Geris L. Combining microCT-based characterization with empirical modelling as a robust screening approach for the design of optimized CaP-containing scaffolds for progenitor cellmediated bone formation. Acta Biomater. 2016;35:330-40.

95. Khan PK, Mahato A, Kundu B, Nandi SK, Mukherjee P, Datta S, Sarkar S, Mukherjee J, Nath S, Balla VK. Influence of single and binary doping of strontium and lithium on in vivo biological properties of bioactive glass scaffolds. Sci Rep. 2016;6:32964.

96. Kim HJ, Lee S, Yun H-W, Yin XY, Kim SH, Choi BH, Kim YJ, Kim MS, Min B-H. In vivo degradation profile of porcine cartilage-derived extracellular matrix powder scaffolds using a non-invasive fluorescence imaging method. J Biomater Sci Polym Ed. 2016;27(2):177-90.

97. Kim J-A, Lim J, Naren R, H-s Y, Park EK. Effect of the biodegradation rate controlled by pore structures in magnesium phosphate ceramic scaffolds on bone tissue regeneration in vivo. Acta Biomater. 2016;44:155-67.

98. Krueger E, Chang AN, Brown D, Eixenberger J, Brown R, Rastegar S, Yocham KM, Cantley KD, Estrada D. Graphene foam as a three-dimensional platform for myotube growth. ACS Biomater Sci Eng. 2016;2(8):1234-41.

99. Kumpová I, Vavřík D, Fíla T, Koudelka P, Jandejsek I, Jakůbek J, Kytýř D, Zlámal P, Vopálenský M, Gantar A. High resolution micro-CT of low attenuating organic materials using large area photon-counting detector. J Instrum. 2016;11(02):C02003.

100. Lappalainen O-P, Karhula S, Haapea M, Kyllönen L, Haimi S, Miettinen S, Saarakkala S, Korpi J, Ylikontiola LP, Serlo WS. Bone healing in rabbit calvarial critical-sized defects filled with stem cells and growth factors combined with granular or solid scaffolds. Childs Nerv Syst. 2016;32(4):681-8.

101. Lappalainen O-P, Karhula SS, Haapea M, Kauppinen S, Finnilä M, Saarakkala S, Serlo W, Sándor GK. Micro-CT analysis of bone healing in rabbit calvarial critical-sized defects with solid bioactive glass, tricalcium phosphate granules or autogenous bone. J Oral Maxillofac Res. 2016;7(2):e4.

102. Lee DY, Park SA, Lee SJ, Kim TH, Oh SH, Lee JH, Kwon SK. Segmental tracheal reconstruction by 3D-printed scaffold: Pivotal role of asymmetrically porous membrane. Laryngoscope. 2016;126(9):e304.

103. Lee JY, Son SJ, Son JS, Kang SS, Choi SH. Bone-healing capacity of PCL/ PLGA/duck beak scaffold in critical bone defects in a rabbit model. BioMed Res Int. 2016;2016:2136215.

104. Levingstone TJ, Thompson E, Matsiko A, Schepens A, Gleeson JP, O'Brien FJ. Multi-layered collagen-based scaffolds for osteochondral defect repair in rabbits. Acta Biomater. 2016;32:149-60.

105. Li H, Fan J, Sun L, Liu X, Cheng P, Fan H. Functional regeneration of ligament-bone interface using a triphasic silk-based graft. Biomaterials. 2016; 106:180-92.

106. Li W, Kang J, Yuan Y, Xiao F, Yao H, Liu S, Lu J, Wang Y, Wang Z, Ren $L$. Preparation and characterization of PVA-PEEK/PVA- $\beta$-TCP bilayered hydrogels for articular cartilage tissue repair. Compos Sci Technol. 2016. 128:58-64. 
107. Liang Y, Wen L, Shang F, Wu J, Sui K, Ding Y. Endothelial progenitors enhanced the osteogenic capacities of mesenchymal stem cells in vitro and in a rat alveolar bone defect model. Arch Oral Biol. 2016;68:123-30.

108. Lin W-J, Zhang D-Y, Zhang G, Sun H-T, Qi H-P, Chen L-P, Liu Z-Q, Gao R-L, Zheng $W$. Design and characterization of a novel biocorrodible iron-based drug-eluting coronary scaffold. Mater Des. 2016;91:72-9.

109. Liu X, Bao C, Xu HH, Pan J, Hu J, Wang P, Luo E. Osteoprotegerin genemodified BMSCs with hydroxyapatite scaffold for treating critical-sized mandibular defects in ovariectomized osteoporotic rats. Acta Biomater. 2016;42:378-88.

110. Lovati A, Lopa S, Recordati C, Talò G, Turrisi C, Bottagisio M, Losa M, Scanziani E, Moretti M. In vivo bone formation within engineered hydroxyapatite scaffolds in a sheep model. Calcif Tissue Int. 2016;99(2):209-23.

111. Lv X, Li Z, Chen S, Xie M, Huang J, Peng X, Yang R, Wang H, Xu Y, Feng C. Structural and functional evaluation of oxygenating keratin/silk fibroin scaffold and initial assessment of their potential for urethral tissue engineering. Biomaterials. 2016;84:99-110.

112. Maiti SK, Ninu AR, Sangeetha P, Mathew DD, Tamilmahan P, Kritaniya D, Kumar N, Hescheler J. Mesenchymal stem cells-seeded bio-ceramic construct for bone regeneration in large critical-size bone defect in rabbit. J Stem Cells Regen Med. 2016;12(2):87.

113. Majumdar S, Pothirajan P, Dorcemus D, Nukavarapu S, Kotecha M. High field sodium MRI assessment of stem cell chondrogenesis in a tissue-engineered matrix. Ann Biomed Eng. 2016;44(4):1120-7.

114. Manescu A, Giuliani A, Mohammadi S, Tromba G, Mazzoni S, Diomede F, Zini N, Piattelli A, Trubiani O. Osteogenic potential of dualblocks cultured with human periodontal ligament stem cells: In vitro and synchrotron microtomography study. J Periodontal Res. 2016;51(1):112-24.

115. Meininger S, Mandal S, Kumar A, Groll J, Basu B, Gbureck U. Strength reliability and in vitro degradation of three-dimensional powder printed strontium-substituted magnesium phosphate scaffolds. Acta Biomater. 2016 31:401-11.

116. Namli H, Erdogan Ö, Gönlüsen G, Kahraman OE, Aydin HM, Karabag S, Tatli $U$. Vertical bone augmentation using bone marrow-derived stem cells: An in vivo study in the rabbit calvaria. Implant Dent. 2016;25(1):54-62.

117. Nau C, Henrich D, Seebach C, Schröder K, Fitzsimmons S-J, Hankel S, Barker $J$ H, Marzi I, Frank J. Treatment of large bone defects with a vascularized periosteal flap in combination with biodegradable scaffold seeded with bone marrow-derived mononuclear cells: An experimental study in rats. Tissue Eng Pt A. 2015;22(1-2):133-41.

118. Neves N, Campos BB, Almeida IF, Costa PC, Cabral AT, Barbosa MA, Ribeiro CC. Strontium-rich injectable hybrid system for bone regeneration. Mater Sci Eng, C. 2016;59:818-27.

119. Novajra G, Boetti NG, Lousteau J, Fiorilli S, Milanese D, Vitale-Brovarone C. Phosphate glass fibre scaffolds: Tailoring of the properties and enhancement of the bioactivity through mesoporous glass particles. Mater Sci Eng, C. 2016;67:570-80.

120. Offeddu G, Ashworth J, Cameron R, Oyen M. Structural determinants of hydration, mechanics and fluid flow in freeze-dried collagen scaffolds. Acta Biomater. 2016;41:193-203.

121. Olubamiji AD, Izadifar Z, Si JL, Cooper DM, Eames BF, Chen DX. Modulating mechanical behaviour of 3D-printed cartilage-mimetic PCL scaffolds: Influence of molecular weight and pore geometry. Biofabrication. 2016;8(2): 025020

122. Park HJ, Min KD, Lee MC, Kim SH, Lee OJ, Ju HW, Moon BM, Lee JM, Park YR, Kim DW. Fabrication of 3D porous SF/ $\beta$-TCP hybrid scaffolds for bone tissue reconstruction. J Biomed Mater Res A. 2016;104(7):1779-87.

123. Pilipchuk SP, Monje A, Jiao Y, Hao J, Kruger L, Flanagan CL, Hollister SJ, Giannobile W. Integration of 3D printed and micropatterned polycaprolactone scaffolds for guidance of oriented collagenous tissue formation in vivo. Adv Healthc Mater. 2016;5(6):676-87.

124. Poudel SB, Bhattarai G, Kim J-H, Kook S-H, Seo Y-K, Jeon Y-M, Lee J-C. Local delivery of recombinant human FGF7 enhances bone formation in rat mandible defects. J Bone Miner Metab. 2017;35(5):485-96.

125. Pripatnanont $P$, Praserttham P, Suttapreyasri S, Leepong N, Monmaturapoj $\mathrm{N}$. Bone regeneration potential of biphasic nanocalcium phosphate with high hydroxyapatite/tricalcium phosphate ratios in rabbit calvarial defects. Int J Oral Maxillofac Implants. 2016;31(2):294-303.

126. Przekora A, Palka K, Ginalska G. Biomedical potential of chitosan/HA and chitosan/ $\beta$-1, 3-glucan/HA biomaterials as scaffolds for bone regeneration A comparative study. Mater Sci Eng, C. 2016;58:891-9.
127. Qi X, Huang Y, Han D, Zhang J, Cao J, Jin X, Huang J, Li X, Wang T. Threedimensional poly ( $\varepsilon$-caprolactone)/hydroxyapatite/collagen scaffolds incorporating bone marrow mesenchymal stem cells for the repair of bone defects. Biomed Mater. 2016;11(2):025005.

128. Qi X, Zhang J, Yuan H, Xu Z, Li Q, Niu X, Hu B, Wang Y, Li X. Exosomes secreted by human-induced pluripotent stem cell-derived mesenchymal stem cells repair critical-sized bone defects through enhanced angiogenesis and osteogenesis in osteoporotic rats. Int J Biol Sci. 2016;12(7):836.

129. Saito K, Anada T, Shiwaku Y, Chiba S, Miyatake N, Suzuki K, Tsuchiya K, Suzuki O. Dose-dependent enhancement of octacalcium phosphate biodegradation with a gelatin matrix during bone regeneration in a rabbit tibial defect model. RSC Advances. 2016;6(69):64165-74.

130. Schouman T, Schmitt M, Adam C, Dubois G, Rouch P. Influence of the overall stiffness of a load-bearing porous titanium implant on bone ingrowth in critical-size mandibular bone defects in sheep. J Mech Behav Biomed. 2016;59:484-96.

131. Shahgholi M, Oliviero S, Baino F, Vitale-Brovarone C, Gastaldi D, Vena P. Mechanical characterization of glass-ceramic scaffolds at multiple characteristic lengths through nanoindentation. J Eur Ceram Soc. 2016:36(9):2403-9.

132. Sharma S, Sapkota D, Xue Y, Sun Y, Finne-Wistrand A, Bruland O, Mustafa K. Adenoviral mediated expression of BMP2 by bone marrow stromal cells cultured in 3D copolymer scaffolds enhances bone formation. PloS one 2016;11(1):e0147507.

133. Sheikh FA, Ju HW, Moon BM, Lee OJ, Kim J-H, Park HJ, Kim DW, Kim D-K, Jang JE, Khang G. Hybrid scaffolds based on PLGA and silk for bone tissue engineering. Tissue Eng Regen M. 2016;10(3):209-21.

134. Shi J, Sun J, Zhang W, Liang H, Shi Q, Li X, Chen Y, Zhuang Y, Dai J. Demineralized bone matrix scaffolds modified by CBD-SDF-1a promote bone regeneration via recruiting endogenous stem cells. ACS Appl Mater Inter. 2016;8(41):27511-22.

135. Suliman S, Sun Y, Pedersen TO, Xue Y, Nickel J, Waag T, FinneWistrand A, Steinmüller-Nethl D, Krueger A, Costea DE. In vivo host response and degradation of copolymer scaffolds functionalized with nanodiamonds and bone morphogenetic protein 2. Adv Healthc Mater. 2016;5(6):730-42.

136. Sun Y, Liu S, Fu Y, Kou X-X, He D-Q, Wang G-N, Fu C-C, Liu Y, Zhou Y-H. Mineralized Collagen Regulates Macrophage Polarization During Bone Regeneration. J Biomed Nanotechnol. 2016;12(11):2029-40.

137. Tagliabue S, Rossi E, Baino F, Vitale-Brovarone C, Gastaldi D, Vena P. MicroCT based finite element models for elastic properties of glass-ceramic scaffolds. J Mech Behav Biomed. 2017;65:248-55.

138. Tan H, Yang S, Liu W, Dai P, Tang T, Li W. Calcium sulfate cement combined with silica-based mesoporous material for bone regeneration: in vitro and in vivo study. Int J Clin Exp Med. 2016;9(11):20907-18.

139. Tang $W$, Lin D, Yu Y, Niu H, Guo H, Yuan Y, Liu C. Bioinspired trimodal macro/micro/nano-porous scaffolds loading rhBMP-2 for complete regeneration of critical size bone defect. Acta Biomater. 2016;32:309-23.

140. Tansik G, Kilic E, Beter M, Demiralp B, Sendur GK, Can N, Ozkan H, Ergul E, Guler MO, Tekinay AB. A glycosaminoglycan mimetic peptide nanofiber gel as an osteoinductive scaffold. Biomater Sci. 2016;4(9):1328-39.

141. Tao Z-S, K-k T, Huang Z-L, Zhou Q, Sun T, Xu H-M, Zhou Y-L, Lv Y-X, Cui W, Yang L. Combined treatment with parathyroid hormone (1-34) and betatricalcium phosphate had an additive effect on local bone formation in a rat defect model. Med Biol Eng Comput. 2016;54(9):1353-62.

142. Tu S, Hu F, Cai W, Xiao L, Zhang L, Zheng H, Jiang Q, Chen L. Visualizing polymeric bioresorbable scaffolds with three-dimensional image reconstruction using contrast-enhanced micro-computed tomography. Int J Cardiovas Imag. 2017:33(5):731-7.

143. Vuornos K, Björninen M, Talvitie E, Paakinaho K, Kellomäki M, Huhtala H, Miettinen S, Seppänen-Kaijansinkko R, Haimi S. Human adipose stem cells differentiated on braided polylactide scaffolds is a potential approach for tendon tissue engineering. Tissue Eng Pt A. 2016;22(5-6):513-23.

144. Wang H, He X-Q, Jin T, Li Y, Fan X-Y, Wang Y, Xu Y-Q. Wnt11 plays an important role in the osteogenesis of human mesenchymal stem cells in a PHA/FN/ALG composite scaffold: possible treatment for infected bone defect. Stem Cell Res Ther. 2016;7(1):18.

145. Wang X-F, Lu P-J, Song Y, Sun Y-C, Wang Y-G, Wang Y. Nano hydroxyapatite particles promote osteogenesis in a three-dimensional bio-printing construct consisting of alginate/gelatin/hASCs. RSC Advances. 2016;6(8): 6832-42. 
146. Xia Y, Zhou P, Wang F, Qiu C, Wang P, Zhang Y, Zhao L, Xu S. Degradability, biocompatibility, and osteogenesis of biocomposite scaffolds containing nano magnesium phosphate and wheat protein both in vitro and in vivo for bone regeneration. Int J Nanomed. 2016;11:3435.

147. Xie Q, Wang Z, Zhou H, Yu Z, Huang Y, Sun H, Bi X, Wang Y, Shi W, Gu P. The role of miR-135-modified adipose-derived mesenchymal stem cells in bone regeneration. Biomaterials. 2016;75:279-94.

148. Yang L, Lu W, Pang Y, Huang X, Wang Z, Qin A, Hu Q. Fabrication of a novel chitosan scaffold with asymmetric structure for guided tissue regeneration. RSC Advances. 2016;6(75):71567-73.

149. Yi S, Yu M, Yang S, Miron RJ, Zhang Y. Tcf12, a member of basic helix-loophelix transcription factors, mediates bone marrow mesenchymal stem cell osteogenic differentiation in vitro and in vivo. Stem Cells. 2017;35(2):386-97.

150. Yu W, Zhao H, Ding Z, Zhang Z, Sun B, Shen J, Chen S, Zhang B, Yang K, Liu M. In vitro and in vivo evaluation of MgF2 coated AZ31 magnesium alloy porous scaffolds for bone regeneration. Colloids Surf B Biointerfaces. 2017; 149:330-40.

151. Yuan X, Smith RJ Jr, Guan H, lonita CN, Khobragade P, Dziak R, Liu Z, Pang M, Wang C, Guan G. Hybrid biomaterial with conjugated growth factors and mesenchymal stem cells for ectopic bone formation. Tissue Eng Pt A. 2016; 22(13-14):928-39.

152. Zhang J, Wang H, Shi J, Wang Y, Lai K, Yang X, Chen X, Yang G. Combination of simvastatin, calcium silicate/gypsum, and gelatin and bone regeneration in rabbit calvarial defects. Scientific Reports. 2016;6:23422.

153. Zhang J, Yang Y, Chen Y, Liu X, Guo S, Zhu L, Wang Y. An in situ phototriggered-imine-crosslink composite hydrogel for bone defect repair. J Mater Chem B. 2016;4(5):973-81.

154. Zhang Y, Yang S, Zhou W, Fu H, Qian L, Miron RJ. Addition of a synthetically fabricated osteoinductive biphasic calcium phosphate bone graft to BMP2 improves new bone formation. Clin Implant Dent R. 2016;18(6):1238-47.

155. Zhou Q, Yu B-H, Liu W-C, Wang Z-L. BM-MSCs and Bio-Oss complexes enhanced new bone formation during maxillary sinus floor augmentation by promoting differentiation of BM-MSCs. In Vitro Cell Dev Biol Anim. 2016; 52(7):757-71.

156. Zidek J, Vojtova L, Abdel-Mohsen A, Chmelik J, Zikmund T, Brtnikova J, Jakubicek R, Zubal L, Jan J, Kaiser J. Accurate micro-computed tomography imaging of pore spaces in collagen-based scaffold. J Mater Sci Mater Med. 2016;27(6):110.

157. Zimmerer $R$, Jehn $P$, Kokemüller $H$, Abedian $R$, Lalk M, Tavassol F, Gellrich N-C, Spalthoff S. In vivo tissue engineered bone versus autologous bone: Stability and structure. Int J Oral Maxillofac Surg. 2017:46(3):385-93

158. Zo SM, Singh D, Singh D, Han SS. Altering kinetics of polymerization can modulate mesenchymal stem cells interaction with 3D matrix. Sci Adv Mater. 2016;8(8):1688-95.

159. Boone JM, Velazquez O, Cherry SR. Small-animal X-ray dose from micro-CT. Mol Imaging. 2004;3(3):15353500200404118.

160. Figueroa SD, Winkelmann CT, Miller WH, Volkert WA, Hoffman TJ. TLD assessment of mouse dosimetry during microCT imaging. Med Phys. 2008; 35(9):3866-74

161. Willekens I, Buls N, Lahoutte T, Baeyens L, Vanhove C, Caveliers V, Deklerck R, Bossuyt A, de Mey J. Evaluation of the radiation dose in micro-CT with optimization of the scan protocol. Contrast Media Mol I. 2010;5(4):201-7.

162. Du Plessis A, Broeckhoven C, Guelpa A, Le Roux SG. Laboratory X-ray microcomputed tomography: A user guideline for biological samples. GigaScience. 2017;6(6):1-11.

163. Ritman EL. Current status of developments and applications of micro-CT. Annu Rev Biomed Eng. 2011;13:531-52.

164. Kruth JP, Bartscher M, Carmignato S, Schmitt R, De Chiffre L, Weckenmann A. Computed tomography for dimensional metrology. CIRP Ann-Manuf Techn. 2011;60(2):821-42

165. Stock SR. Microcomputed tomography: Methodology and applications. Boca Raton, FL: CRC press, 9; 2008.

166. Morris DE, Mather ML, Simon CG Jr, Crowe JA. Time-optimized X-ray microCT imaging of polymer based scaffolds. J Biomed Mater Res B Appl Biomater. 2012;100((2):360-7.

167. De Chiffre L, Carmignato S, Kruth J-P, Schmitt R, Weckenmann A. Industrial applications of computed tomography. CIRP Ann-Manuf Techn. 2014:63(2):655-77.
168. Nazarian A, Snyder BD, Zurakowski D, Müller R. Quantitative microcomputed tomography: a non-invasive method to assess equivalent bone mineral density. Bone. 2008;43(2):302-11.

169. Barrett JF, Keat N. Artifacts in CT: Recognition and avoidance. Radiographics. 2004;24(6):1679-91.

170. Boas FE, Fleischmann D. CT artifacts: Causes and reduction techniques. Imaging Med. 2012;4(2):229-40.

171. Sweedy A, Bohner M, van Lenthe GH, Baroud G. A novel method for segmenting and aligning the pre-and post-implantation scaffolds of resorbable calcium-phosphate bone substitutes. Acta Biomater. 2017; 54:441-53.
Ready to submit your research? Choose BMC and benefit from:

- fast, convenient online submission

- thorough peer review by experienced researchers in your field

- rapid publication on acceptance

- support for research data, including large and complex data types

- gold Open Access which fosters wider collaboration and increased citations

- maximum visibility for your research: over $100 \mathrm{M}$ website views per year

At BMC, research is always in progress.

Learn more biomedcentral.com/submissions 